\title{
Pengaruh Kepemimpinan Transformasional, Komitmen Organisasi, dan Kompetensi Sumber Daya Manusia terhadap Penerapan Anggaran Berbasis Kinerja pada Badan Pendapatan Daerah Kabupaten Jember
}

\author{
Any Rumiyati Ningtias ${ }^{1 *}$, Arik Susbiyani², Nina Martiana ${ }^{3}$ \\ 1,2,3Program Studi Akuntansi, Fakultas Ekonomi, Universitas Muhammadiyah Jember, Jawa Timur, Indonesia
}

\author{
A R T I C L E I N F O \\ Article history: \\ Received 19 August 2019 \\ Received in revised form \\ 16 September 2019 \\ Accepted 15 October 2019 \\ Available online 30 \\ November 2019 \\ Kata Kunci: \\ Kepemimpinan \\ Transformasional, \\ Komitmen Organisasi, \\ Kompetensi Sumber Daya \\ Manusia, Penerapan \\ Anggaran Berbasis Kinerja \\ Keywords: \\ Transformational \\ Leadership, Organizational \\ Commitment, Human \\ Resource Competency, \\ Implementation of \\ Performance-Based Budgets
}

\begin{abstract}
A B S T R A K
Penelitian ini bertujuan untuk menguji pengaruh kepemimpinan transformasional, komitmen organisasi, dan kompetensi sumber daya manusia terhadap penerapan anggaran berbasis kinerja pada Badan Pendapatan Daerah Kabupaten Jember. Data diperoleh dari 77 kuesioner yang disebar pada Bapenda Kabupaten Jember. Hasil jawaban responden dalam kuesioner tersebut selanjutnya diolah dan diuji menggunakan SPP. Hasil penelitian ini menunjukkan bahwa variabel kepemimpinan transformasional dan komitmen organisasi tidak berpengaruh signifikan terhadap penerapan anggaran berbasis kinerja. Namun kompetensi sumber daya manusia berpengaruh signifikan terhadap penerapan anggaran berbasis kinerja.
\end{abstract}

\section{A B S T R A C T}

The aim of this study was to determine the effect of transformational leadership, organizational commitment, and human resource competencies on the implementation of performance-based budgets in Badan Pendapatan Daerah (Bapenda) Kabupaten Jember. The data was obtained from 77 questionnaire distributed to Bapenda Kabupaten Jember. The results of the respondent's answers in the questionnaire were processed and tested using SPSS. The results of this study indicate that the national transfer leadership and organizational commitment variables haven't significant effect on the implementation of performance-based budgets. In otherhand, the competence of human resources had significant effect on the influences the application of performance-based budgets.

\footnotetext{
* Corresponding author.

E-mail addresses: rumiyatianyy@gmail.com (Any Rumiyati Ningtias)
} 


\section{Pendahuluan}

Masa era reformasi saat ini, terdapat tuntutan untuk meningkatkan kinerja organisasi sektor publik agar lebih berorientasi pada terwujudnya good public governance and good corporate governance (Mardiasmo, 2009:27). Pemerintah sebagai organisasi sektor publik terbesar bertanggung jawab penuh untuk mewujudkan good governance dengan cara menjalankan aspek-aspek fungsional pemerintah secara efektif dan efisien. Kondisi ini mendorong berkembangnya wacana perlunya reformasi keuangan dan anggaran agar pengalokasian anggaran lebih berorientasi pada kepentingan publik melalui anggaran berbasis kinerja.

Pendekatan penganggaran yang berbasis kinerja sangat diperlukan bagi suatu kerja instansi pemerintah yang memberikan pelayanan kepada publik. Secara khusus, penerapan anggaran berbasis kinerja dilaporkan dalam bentuk Laporan Kinerja. Laporan Kinerja merupakan bentuk akuntabilitas dari pelaksanaan tugas dan fungsi yang dipercayakan kepada setiap instansi pemerintah atas penggunaan anggaran.

Kepemimpinan adalah akibat dari pengaruh yang berasal satu arah, sebab pemimpin yang mungkin telah memiliki kualitas-kualitas tertentu yang mampu membedakan akan dirinya dan pengikutnya (Moejiono, 2002). Menurut Robbin (2010) menyatakan kepemimpinan transformasional adalah pemimpin yang selalu membirikan perhatian pada bawahannya dengan cara memberi antusiasme dan dorongan untuk mencapai tujuannya.

Komitmen adalah suatu janji yang diucapkan seseorang kepada dirinya sendiri dan orang lain, yang dicerminkan dari setiap tindakan atau pun perilaku yang dijalankannya. Organisasi merupakan sekelompok orang yang terikat secara formal dalam hubungan atasan dan bawahan yang bekerja sama untuk mencapai tujuan bersama (Kast dan James E. Rosenzweig, 2002). Komitmen organisasi adalah mencerminkan sejauhmana individu lebih mementingkan organisasinya daripada kepentingan individu, sehingga individu menjadi loyal terhadap organisasinya (Robbin, 2007).

Kompetensi adalah kemampuan atau kapasitas seseorang untuk mengerjakan berbagai tugas dalam suatu pekerjaan, dimana kemampuan ini ditentukan berbagai tugas dalam suatu bekerjaan, dimana kemampuan ini ditentukan dua faktor yang kemampuan intelektual dan kemampuan fisik (Robbin, 2007). Menurut Mangkunegara (2012) kompetensi sumber daya manusia adalah kompetensi yang berhubungan dengan pengetahuan, kemampuan, dan karakteristik kepribadian yang mempengaruhi secara langsung terhadap kinerjanya. Penerapan anggaran berbasis kinerja adalah sebuah sistem anggaran yang berorientasi pada output organisasi dan berkaitan erat dengan visi, misi, dan rencana strategis (Bastian, 2006).

Sebagai salah satu bagian dari pemerintah Kabupaten Jember yang melaksanakan Good governance, Badan Pendapatan Daerah Kabupaten Jember telah menerapkan anggaran berbasis kinerja. Badan Pendapatan Daerah Kabupaten Jember dibentuk berdasarkan Peraturan Daerah Kabupaten Jember Nomor 3 Tahun 2016 tentang Perangkat Daerah, dan berdasarkan Peraturan Bupati Jember Nomor 59 Tahun 2016 tentang Kedudukan, Susunan organisasi, Tugas dan Fungsi serta Tata Kerja Badan Pendapatan Daerah Kabupaten Jember. Badan Pendapatan Daerah merupakan unsur penunjang urusan pemerintahan di bidang keuangan. Berdasarkan data pencapaian kinerja pelayanan di Badan Pendapatan Daerah Kabupaten Jember sudah membuat laporan kinerja setidaknya mulai Tahun 2011.

Pada Tabel 1 Menunjukkan bahwa Realisasi Kinerja Kabupaten Jember perkembangannya selama 4 Tahun mengalami penurunan yang melalui Laporan Kinerja yang dapat diketahui dalam tingkat keberhasilan Badan Pendapatan Daerah Kabupaten Jember, dalam merealisasikan target-target yang telah ditetapkan. Hasil Realisasi Kinerja Tahun 2014 - 2017 sebagai berikut:

Tabel 1. Realisasi Kinerja Tahun $2014-2017$

\begin{tabular}{lcccc}
\hline \multicolumn{1}{c}{ Sasaran strategis } & Indikator sasaran & Tahun & Target & Realisasi \\
\hline Mewujudkan & Jumlah Realisasi & 2014 & Rp 126,80 Miliyar & Rp 119,14 Miliyar \\
peningkatan & Penerimaan & 2015 & Rp 131,48 Miliyar & Rp 125,07 Miliyar \\
Pendapatan Asli & Pendapatan Asli & 2016 & Rp 525,00 Miliyar & Rp 524,14 Miliyar \\
Daerah & Daerah (PAD) & 2017 & Rp 736,93 Miliyar & Rp 719,11 Miliyar \\
\hline
\end{tabular}

Sumber data: Badan Pendapatan Daerah Kabupaten Jember

Mengingat penerapan anggaran berbasis kinerja merupakan salah satu faktor penting terciptanya good governance dan penerapan anggaran berbasis kinerja dapat dipengaruhi oleh kepemimpinan transformasional, komitemen organisasi, dan kompetensi sumber daya manusia, maka peneliti akan menganalisa "Pengaruh Kepemimpinan Transformasional, Komitmen Organisasi, Dan Kompetensi Sumber 
Daya Manusia Terhadap Penerapan Anggaran Berbasis Kinerja pada Badan Pendapatan Daerah Kabupaten Jember.

\section{Metode}

Data yang digunakan adalah data primer yang dikumpulkan melalui penyebaran kuesioner. Jenis data yang digunakan yaitu jenis data subyek. Data subyek adalah jenis data yang berupa pendapat, sikap, pengalaman, atau karakteristik dari seseorang atau sekelompok orang yang menjadi subyek penelitian atau responden.

Populasi yang dipilih dalam penelitian ini adalah semua pegawai Badan Pendapatan Daerah Kabupaten Jember yang berjumlah 84 responden. Teknik yang akan digunakan dalam penelitian adalah purposive sampling. Sampel dalam penelitian ini berjumlah 77 responden.

Metode penelitian yang digunakan yaitu penelitian kuantitatif dengan teknik analisis data dalam penelitian ini menggunakan regresi berganda dengan bantuan program statistik SPSS versi 21.

Persamaan yang digunakan adalah:

$$
\mathrm{Y}=\mathrm{a}+\mathrm{bx}_{1}+\mathrm{bx}_{2}+\mathrm{bx}_{3}+\mathrm{e}
$$

Dimana:

$\begin{array}{ll}\mathrm{Y} & =\text { Penrapan Anggaran Berbasis Kinerja } \\ \mathrm{a} & =\text { Konstanta } \\ \mathrm{b} & =\text { Koefisien Regresi } \\ \mathrm{X} 1 & =\text { Kepemimpinan Transformasional } \\ \mathrm{X} 2 & =\text { Komitemen Organisasi } \\ \mathrm{X} 3 & =\text { Kompetensi Sumber Daya Manusia } \\ \mathrm{e} & =\text { Standart Error Estimate }\end{array}$

\section{Hasil dan Pembahasan}

\section{A. Uji Validitas}

Uji validitas bertujuan untuk mengukur sah tidaknya suatu kuesioner (Ghozali, 2006), dapat disimpulkan bahwa koefisien kolerasi (r) yang dihasilkan oleh masing-masing item pertanyaan nilainya telah lebih besar dari 0,05. Sehingga data-data yang digunakan dalam penelitian ini telah valid. Karena $r$

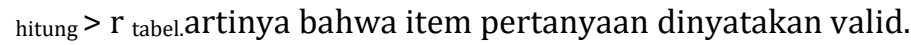

\section{B. Uji Reliabilitas}

Reliabilitas digunakan sebagai alat pengumpul data karena instrumen sudah baik. Pengujian reabilitas bertujuan untuk mengukur suatu kuesioner yang merupakan indikator dari variabel.

Tabel 2. Hasil Uji Reliabilitas

\begin{tabular}{clccc}
\hline No & \multicolumn{1}{c}{ Variabel Penelitian } & Alpha & Batas Kritis & Kesimpulan \\
\hline 1 & Kepemimpinan Transformasional (X1) & 0,860 & 0,60 & Reliabel \\
2 & Komitmen Organisasi (X2) & 0,612 & 0,60 & Reliabel \\
3 & Kompetensi Sumber Daya Manusia (X3) & 0,881 & 0,60 & Reliabel \\
4 & Penerapan Anggaran Berbasis Kinerja (Y) & 0,852 & 0,60 & Reliabel \\
\hline
\end{tabular}

Hasil diatas menyatakan bahwa semua konsep pengukuran masing-masing variabel dari kuesioner adalah reliabel. Sehingga untuk selanjutnya item-item pada masing-masing konsep variabel tersebut layak digunakan sebagai alat ukur. 


\section{Uji Asumsi Klasi}

a) Uji Normalitas

Uji normalitas bertujuan untuk mengetahui apakah dalam model regresi yang diajukan dalam penelitiaan, variabel pengganggu berdistribusi normal atau tidak.

Tabel 3. Hasil Uji Normalitas

\begin{tabular}{clcl}
\hline No & \multicolumn{1}{c}{ Variabel } & $\begin{array}{c}\text { Nilai Kolmogorov } \\
\text { Smirnov }\end{array}$ & Keterangan \\
\hline 1 & Kepemimpinan & 0,051 & Berdistribusi Normal \\
2 & Transformasional (X1) & 0,067 & Berdistribusi Normal \\
3 & Komitmen Organisasi (X2) & 0,053 & Berdistribusi Normal \\
\hline
\end{tabular}

Dari Tabel 3 menunjukkan bahwa nilai signifikan yang dihasilkan pada masing-masing variabel telah lebih dari 0,05. Sehingga dapat disimpulkan bahwa Ho ditolak, hal ini berarti data-data yang ada pada penelitian ini telah layak digunakan karena terbukti telah berdistribusi normal.

\section{b) Uji Multikolinearitas}

Uji multikolinearitas bertujuan untuk menguji apakah model regresi ditemukan adanya kolerasi antar variabel bebas.

Tabel 4. Hasil Uji Multikolinearitas

\begin{tabular}{|c|c|c|c|c|}
\hline \multirow{2}{*}{ No } & \multirow{2}{*}{ Variabel Bebas } & \multicolumn{2}{|c|}{ Collinearity statistic } & \multirow{2}{*}{ Keterangan } \\
\hline & & Tolerance & VIF & \\
\hline 1 & Kepemimpinan Transformasional & 0,902 & 1,108 & $\begin{array}{c}\text { Tidak ada } \\
\text { multikolinieritas }\end{array}$ \\
\hline 2 & Komitmen Organisasi & 0,925 & 1,081 & $\begin{array}{c}\text { Tidak ada } \\
\text { multikolinieritas }\end{array}$ \\
\hline 3 & Kompetensi Sumber Daya Manusia & 0,968 & 1,033 & $\begin{array}{c}\text { Tidak ada } \\
\text { multikolinieritas }\end{array}$ \\
\hline
\end{tabular}

Dari Tabel 4 menunjukkan bahwa nilai Tolerance tidak ada variabel independen yang memiliki nilai Tolerance kurang dari 0,10 dengan nilai Tolerance masing-masing variabel independen. Hasil perhitungan VIF menunjukkan tidak adanya nilai VIF legih dari 10 dengan nilai masing-masing variabel independen. Dapat disimpulkan bahwa tidak ada multikolinieritas antar variabel independen dalam model regresi.

\section{c) Uji Heterokedastisitas}

Uji Heterokedastisitas bertujuan untuk mengetahui ada atau tidaknya gejala heterokedastisitas dalam model penelitian yang digunakan.

Tabel 5. Hasil Heterokedastisitas

\begin{tabular}{clcc}
\hline No & \multicolumn{1}{c}{ Variabel Bebas } & Nilai t & Sig. \\
\hline 1 & Kepemimpinan Transformasional & 0,597 & 0,553 \\
2 & Komitmen Organisasi & 1,814 & 0,74 \\
3 & Kompetensi Sumber Daya Manusia & $-0,113$ & 0,911 \\
\hline & Variabel Terikat = Residual & & \\
\hline
\end{tabular}

Dari Tabel 5 menunjukkan bahwa uji heterokedastisitas dapat diketahui bahwa seluruh variabel bebas memiliki nilai signifikan lebih besar dari 0,05 , jadi variabel bebas tidak dapat berpengaruh signifikan dengan residual, artinya residual konstan tidak mengikuti perubahan variabel bebas. Sehingga dalam model regresi tidak terjadi heterokedastisitas. 


\section{d) Analisis Linier Berganda}

Alat analisis linier berganda yang digunakan untuk melihat pengaruh beberapa variabel independen terhadap satu variabel independen.

Tabel 6. Hasil Analisis Regresi Linier Berganda

\begin{tabular}{ccccc}
\hline Variabel & Koef. Regresi & thitung & Sig & Keterangan \\
\hline Konstanta & 9,239 & 2,593 & 0,011 & - \\
X1 & 0,018 & 0,306 & 0,760 & Signifikan \\
X2 & 0,124 & 1,812 & 0,074 & Signifikan \\
X3 & 0,256 & 3,178 & 0,002 & Signifikan \\
\hline
\end{tabular}

Hasil diatas dapat diketahui persamaan regresi yang terbentuk adalah:

$\mathrm{Y}=\mathrm{a}+\mathrm{b} 1 \mathrm{X} 1+\mathrm{b} 2 \mathrm{X} 2+\mathrm{b} 3 \mathrm{X} 3+\mathrm{e}$

$\mathrm{Y}=9,239+0,018 \mathrm{X} 1+0,124 \mathrm{X} 2+0,256 \mathrm{X} 3+\mathrm{e}$

Keterangan:
$\mathrm{Y}=$ Penerapan Anggaran Berbasis Kinerja
$\mathrm{X} 1$ = Kepemimpinan Transformasional
$\mathrm{X} 2$ = Komitmen Organisasi
X3 = Kompetensi Sumber Daya Manusia
$\mathrm{e} \quad=$ Standart Error Estimate

Hasil persamaan regresi berganda tersebut, dijabarkan sebagai berikut:

a. Nilai konstanta 9,239, menunjukkan bahwa jikaa tidak ada aktivitas pada kepemimpinan transformasional, komitmen organisasi, dan kompetensi sumber daya manusia maka nilai tingkat penerapan anggaran berbasis kinerja sebesar 9,239.

b. Nilai koefisien 0,018 pada kepemimpinan transformasional, menunjukkan bahwa setiap kenaikan kepemimpinan transformasional maka hal tersebut akan meningkatkan penerapan anggaran berbasis kinerja sebesar 0,018 .

c. Nilai koefisien 0,124 pada komitmen organisasi menunjukkan bahwa setiap kenaikan komitmen organisasi maka hal tersebut akan meningkatkan penerapan anggaran berbasis kinerja sebesar 0,124.

d. Nilai koefisien 0,256 pada kompetensi sumber daya manusia, menunjukkan bahwa setiap kenaikan kompetensi sumber daya manusia maka hal tersebut akan meningkatkan penerapan anggaran berbasis kinerja sebesar 0,256.

\section{Uji Hipotesis}

\section{a) Uji Parsial (Uji T)}

Uji t digunakan untuk menunjukkan seberapa jauh pengaruh satu variabel indenpenden secara individual dalam menerangkan variabel dependen.

Tabel 7. Uji Parsial (Uji t)

\begin{tabular}{|c|c|c|c|c|}
\hline Model & $\begin{array}{c}\text { Unstandardized } \\
\text { Coefficients }\end{array}$ & $\mathbf{t}$ & Sig & Hasil \\
\hline & B & & & \\
\hline Konstanta & 9,239 & 2,593 & 0,011 & - \\
\hline X1 & 0,018 & 0,306 & 0,760 & Tidak berpengaruh signifikan \\
\hline $\mathrm{X} 2$ & 0,124 & 1,812 & 0,074 & Tidak berpengaruh signifikan \\
\hline $\mathrm{X} 3$ & 0,256 & 3.178 & 0,002 & Berpengaruh signifikan \\
\hline
\end{tabular}

Dari tabel tersebut diketahui signifikansi tabel adalah sebagai berikut:

a) Variabel kepemimpinan transformasional (X1) memiliki nilai $t$ hitung $(0,306)<\mathrm{t}$ tabel $(1,993)$ dan signifikansi $0,760>0,05$, maka Ho diterima dan $\mathrm{H} 1$ ditolak, yang berarti secara parsial kepemimpinan transformasional tidak berpengaruh signifikan terhadap penerapan anggaran berbasis kinerja.

b) Variabel komitmen organisasi (X2) memiliki $t$ hitung $(1,812)<t$ tabel $(1,993)$ dan signifikansi $0,074>$ 0,05, maka Ho diterima dan H2 ditolak, yang berarti secara parsial komitmen organisasi tidak berpengaruh signifikan terhadap penerapan anggaran berbasis kinerja. 
c) Variabel kompetensi sumber daya manusia (X3) memiliki $t$ hitung $(3,178)>t$ tabel $(1,993)$ dan signifikansi 0,002 < 0,05, maka Ho ditolak dan H3 diterima, yang berarti secara parsial kompetensi sumber daya manusia berpengaruh signifikan terhadap penerapan anggaran berbasis kinerja.

\section{b) Uji Koefisien Determinasi}

Uji koefisien determinasi bertujuan untuk mengukur seberapa jauh kemampuan model dalam menerngkan variabel dependen. Dalam hal ini koefisien determinasi digunakan untuk mengetahui seberapa jauh total quality managemen (TQM) melalui indikator-indikator variabel.

Tabel 8. Uji Koefisien Determinasi

\begin{tabular}{cccc}
\hline R & R Square & Adjusted R Square & Std. Error of the Estimate \\
\hline 0,421 & 0,177 & 0,144 & 1,92868 \\
\hline
\end{tabular}

Dari Tabel 8 diatas menunjukkan bahwa adjusted R2 adalah 0,177 yang berarti sebanyak 17,7\% variasi variabel penerapan anggaran berbasis kinerja yang dapat dijelaskan oleh ketiga variabel independen sebesar $(100 \%-17,7 \%=82,3 \%)$ dijelaskan oleh sebab-sebab yang lain diluar variabel yang ditentukan.

\section{Simpulan dan Saran}

Dari hasil pembahasan pada bab sebelumnya dapat diambil beberapa kesimpulan. Diantaranya: a). Hasil pengujian hipotesis telah membuktikan terdapat kepemimpinan transformasional tidak berpengaruh signifikan terhadap penerapan anggaran berbasis kinerja. Hal ini kepemimpinan transformsional ini sangat rendah, maka anggaran juga menjadi buruk pada Bapenda Kabupaten Jember. b). Hasil pengujian hipotesis telah membuktikan terdapat komitmen organisasi tidak berpengaruh signifikan terhadap penerapan anggaran berbasis kinerja. Hal ini komitmen yang tidak terlalu tinggi dikarenakan adanya mutasi atau pindah di bidang lain yang mengakibatkan tidak signifikan pada Bapenda Kabupaten Jember. c). Hasil pengujian hipotesis telah membuktikan terdapat kompetensi sumber daya manusia terhadap penerapan anggaran berbasis kinerja. hal ini kompetensi sumber daya manusia sering menggunakan kreativitas yang dimiliki karyawan Bapenda Kabupaten Jember dalam menyelesaikan pekerjaannya.

Adapun saran-saran yang dapat diberikan antara lain: dengan menggunakan objek yang lain, sehingga hasil yang diperoleh dapat mendukung penelitian sebelumnya. Penelitian selanjutnya dapat menambah variabel yang dapat mempengaruhi penerapan anggaran berbasis kinerja.

\section{Daftar Rujukan}

Abdurrahmat Fathoni, 2006. Manajemen Sumber Daya Manusia. Bandung : Rineka Cipta.

Allen, N. J., dan Meyer, J. P. 1991. The Measurement and antecedents of Affective, Continuance and Normative Commitment to the Organization. Journal of Occupational Psychology. 63, 1-18.

Arsyad Azhar, 2012. Media Pembelajaran Cetakan Ke-15. Jakarta: Rajawalli Pers.

Benar Baik Sembiring. 2009. "Faktor-Faktor Yang Mempengaruhi Penyusunan Anggaran Pendapatan Dan Belanja Daerah Berbasis Kinerja (Studi Empiris Si Pemerintah Kabupaten Karo)". Tesis. Medan: Pascasarjana Universitas Sumatera Utara.

Edison, Emron, Anwar, Yohny dan Komariyah, Imas. 2016. Manajemen Sumber Daya Manusia. Cetakan ke1. Bandung : Alfabeta.

Fremont, E. K., \& Rosenzweig, E. J. (2002). Organisasi dan Manajemen. Edisi keempat, Jakarta: Bumi Aksara.

Hutapea Parulian dan Nurianna Thoha. 2008. Kompetensi Plus. PT. Gramedia. Pustaka Utama: Jakarta.

Imam Ghozali. 2006. Aplikasi Analisis Multivariat Dengan Program SPSS. Erlangga, Jakarta. 
Khairina Nur Izzaty. 2011. "Pengaruh Gaya Kepemimpinan dan Kualitas Sumber Daya Manusia Terhadap Penerapan Anggaran Berbasis Kinerja Badan Layanan Umum Studi pada BLU. Universitas Diponegoro Semarang). Skripsi. Fakultas Ekonomi. Universitas Diponegoro Semarang.

Mangkunegara, Anwar P. 2011. Manajemen Sumber Daya Manusia Perusahaan PT Remaja Rosdakarya. Bandung

Mardiasmo. 2002. “Otonomi Daerah Sebagai Upaya Memperkokoh Basis Perekonomian Daerah”. Artikel. Th. 1 - No.4.

Mardiasmo. 2009. “Akuntansi Sektor Publik”. Yogyakarta: Andi.

Moejiono, Imam. 2002. Kepemimpinan dan Keorganisasian. Yogyakarta : UII Pres.

P. Stephen Robbins, 2007. Organizational Behavior. Jakarta : Salemba Empat.

Robbins, Stephen P. Dan Coulter, Mary. 2010. Manajemen Edisi Kesepuluh. Jakarta: Penerbit Erlangga

Peraturan Bupati Nomor 59 Tahun 2016 Tentang Kedudukan, Susunan Organisasi, Tugas dan Fungsi serta Tata Kerja

Peraturan Daerah Nomor 3 Tahun 2016 Tentang Perangkat Daerah 